\title{
Enhancing ecosystem services for flood mitigation: a conservation strategy for peri-urban landscapes?
}

\author{
$\underline{\text { José Barbedo }}^{1}, \underline{\text { Marcelo Miguez }}^{1,2}, \underline{\text { Dan van der Horst }}^{3}$ and $\underline{\text { Monique Marins }}^{1}$
}

\begin{abstract}
A key reason why some ecosystem services are undervalued is because they are not easily perceived both by beneficiaries and potential providers. Hydrological modeling allows us to assess, quantify, and visualize the causal link between a particular human intervention and the positive or negative impacts this has on flooding. This study uses such a model to test hypothetical changes in land use in the Brazilian coastal city of Paraty. We discuss how the adoption of higher density patterns of urban development can respond to the needs of a growing population, while safeguarding cultural landscapes of high environmental value against unsustainable urban sprawl and encroachment. Results of the modeling exercise show how water-flow regulation services can be improved, and to what extent restoring natural functions and properties of peri-urban floodplains may reduce urban flooding.
\end{abstract}

Key Words: ecosystem services; flood risk management; land use adaptation; peri-urban landscapes; water flow regulation

\section{INTRODUCTION}

In this study, cultural landscapes are understood as the set of natural and man-made forms that, in a given moment and from a certain human perspective, express the heritage of successive relationships between humans and nature. The cultural landscape category was added to the World Heritage Convention in 1992 as a recognition of the singularity of different territories, where the relation between culture and natural environment provides a unique identity to each specific landscape. Accordingly, the services provided by ecosystems for human welfare within a certain cultural landscape, may be the result of ecological processes "in natura", as well as the consequence of cumulative human actions over time and within a specific space. The relationship between human development and natural endowment is both dynamic and contextual, but there are a few recurring themes which can play a prominent role in the evolution of otherwise very diverse cultural landscapes. One such recurring theme is the relationship between development patterns and (altered) hydrology. We explore this specific theme, focusing on the way hypothetical land use change processes in human dominated landscapes may affect water-flow regulation services.

The growing emphasis on the importance of water-flow regulation services for flood prevention is conspicuous in the literature on ecosystem services (e.g., Acharya 2000, Emerton 2005, Batker et al. 2010). The European Water Framework Directive (Directorate-General Environment 2011) has encouraged interventions in flood mitigation that sought "to work with nature rather than against it", recognizing that mitigating flooding effects through land use adaptation measures are "better environmental options" (Article 4.7 of the Water Framework Directive). There is a wealth of literature on the benefits of adapting land use change processes for the mitigation of flood risks (e. g., Kousky et al. 2011). Regarding the implementation of these strategic interventions, two fundamental approaches are found in the literature: one that emphasizes the need to halt further consumption of land resources by promoting compact cities (Rogers 1997), proposing a radical reframing or a reversal of the current trend of urban growth. Such an approach explores the possibilities put forward by river restoration and the adaptation of peri-urban floodplains to accommodate the flood waters during and after an event through upstream storage (Mitchell et al. 2006). The second approach attempts to deal with urbanization processes by developing innovative drainage-related concepts such as the North-American concept of Low Impact Development (US Department of Defense 2004, Kloss and Calarusse 2006), the Water Sensitive Urban Design concept developed in Australia (BMT WBM 2009) and the British concepts of Sustainable Urban Drainage Systems (Andoh and Iwugo 2002). Such concepts emphasize the need to combine structural and nonstructural measures to mitigate flood risks (Mascarenhas and Miguez 2002), in order to reduce the impacts of urbanization by improving resilience to changes in the hydrological cycle, enhancing infiltration and water storage by both creating multifunctional landscapes and regulating construction standards.

The adoption of these conceptual approaches in peri-urban landscapes raises two generic challenges: (1) how to promote the preservation of (which) existing natural functions and services, and (2) how should new technologies be utilized for further conversion and transformation of land and water resources. Periurban floodplains are subject to severe socioeconomic pressures for further development, posing a big challenge to sustaining critical water-flow regulation services. Since private net benefits of conversion often exceed those of preservation (Vuuren and Roy 1993), the appraisal of structural measures for flood alleviation is often conducted much more thoroughly than nonstructural measures. In this regard, Corkindale (2007) notes that until nonstructural and structural measures are appraised on equal terms, and in as much detail as traditional hard engineering solutions, it is overwhelmingly probable that the second will be preferred to the first. Schuyt (2005) argues in an overview paper that policy makers do not understand the full economic value of floodplains and that conservation is a genuine option to consider, especially in the light of wider use or damage. Underestimating the range of ecosystem services that an area can provide is likely to result in inappropriate use and this in turn may bring even lower economic benefits (Haller 2010). In such contexts, there is a need to measure and communicate water-flow regulation services

\footnotetext{
${ }^{1}$ Universidade Federal do Rio de Janeiro (UFRJ), Programa de Engenharia Civil, Instituto Alberto Luiz Coimbra de Pós-Graduação (COPPE), ${ }^{2}$ Universidade Federal do Rio de Janeiro (UFRJ), Escola Politécnica, ${ }^{3}$ University of Edinburgh, School of Geosciences, Institute of Geography and the Lived Environment
} 
within the local context of decision making and within the local landscape where the conflict between development and conservation is played out. Knowledge about ecosystem services and landscape values should be clearly communicated, and made easily accessible to policy makers, other stakeholders, and members of the public (De Groot et al. 2010). This is even more challenging in the Global South, where the need for development is hard to challenge and where the battle for conservation is largely focused on pristine natural areas.

By examining specific issues concerning water-flow regulating services in peri-urban landscapes, we highlight the role of land use in reducing flood risks. Present and future scenarios are tested in our study area, estimating their impacts on urban flooding with the aid of a hydrological model. The results obtained from the modeling exercise will enable us to explore "what if" questions based on the measurement of the hydrological benefits of a set of interventions designed to restore natural properties and functions of the river basins in our case study area. Our analysis will allow us to ask to what extent may the optimization of waterflow regulation services in peri-urban floodplains reduce urban flooding? And how useful is it to consider this specific ecosystem service for the conservation of cultural landscapes?

\section{DESCRIPTION OF THE STUDY AREA}

The leading Brazilian urban planner Lucio Costa has described Paraty as the city where the ways of the sea and the paths of the earth meet and interlock. This short description synthesizes the unique landscape that surrounds one of the most valuable colonial settlements in South America. Located in the Rio de Janeiro state (see Fig. 1) between the two larger Brazilian metropolitan areas, Paraty is a lasting materialization of colonialism, resulting from various cycles of resource extraction in Brazil, from the so-called "gold cycle" of the XVIII century to the coffee monocultures of the Paraíba Valley. Surrounded by islands and a succession of mountains, the city is framed by the exuberant vegetation of the Atlantic Forest, often enveloped by a morning fog. According to Cury (2002), Paraty is distinguishable from other historical settlements because of the constant interactions and interconnections among the forest, the sea, and the city. The cultural landscape around Paraty was crucial for its recognition in 1966 as a National Cultural Heritage site, including aspects of environmental diversity and concerns about the preservation of the existing natural resources, as well as the role of local communities in the use of these resources. Recognized as a unique historic gem in 21 st century Brazil, Paraty is a UNESCO World Heritage candidate. Noteworthy, the latest response of UNESCO to this candidacy stressed the need for a more thorough consideration of the environmental setting in which the city is located. The diagnosis conducted for the candidacy process by the Brazilian Institute for Historical and Architectural Heritage (IPHAN) identified many natural and cultural values of the areas surrounding the city which overlay with the water-flow regulation services of the floodplain.

When the first Portuguese settled in this site in the 16th century, the area was composed of wetlands, which were since progressively drained for the construction of the colonial town. The remnants of the floodplain which were not urbanized have been converted for agricultural use, serving as a buffer zone between the city and the mountains. The two river systems flowing into the urban area (Mateus Nunes and Perequê Açu) have steep gradients, bringing rapid discharges of large volumes of storm water onto the floodplain. The original settlement was planned to cope with regular high tides and common flooding events; the streets were deliberately designed in a "V" shape, sloping down from the curbs towards the center, in order to keep the houses dry while the streets turned into canals. Today, this fragile balance between the city and its natural environment is threatened by unplanned urban expansion, which in turn may also be aggravated by more frequent extreme rainfall events as registered in recent times.

Fig. 1. Location of the Pereque-Açu and Mateus Nunes river basins in the Rio de Janeiro State

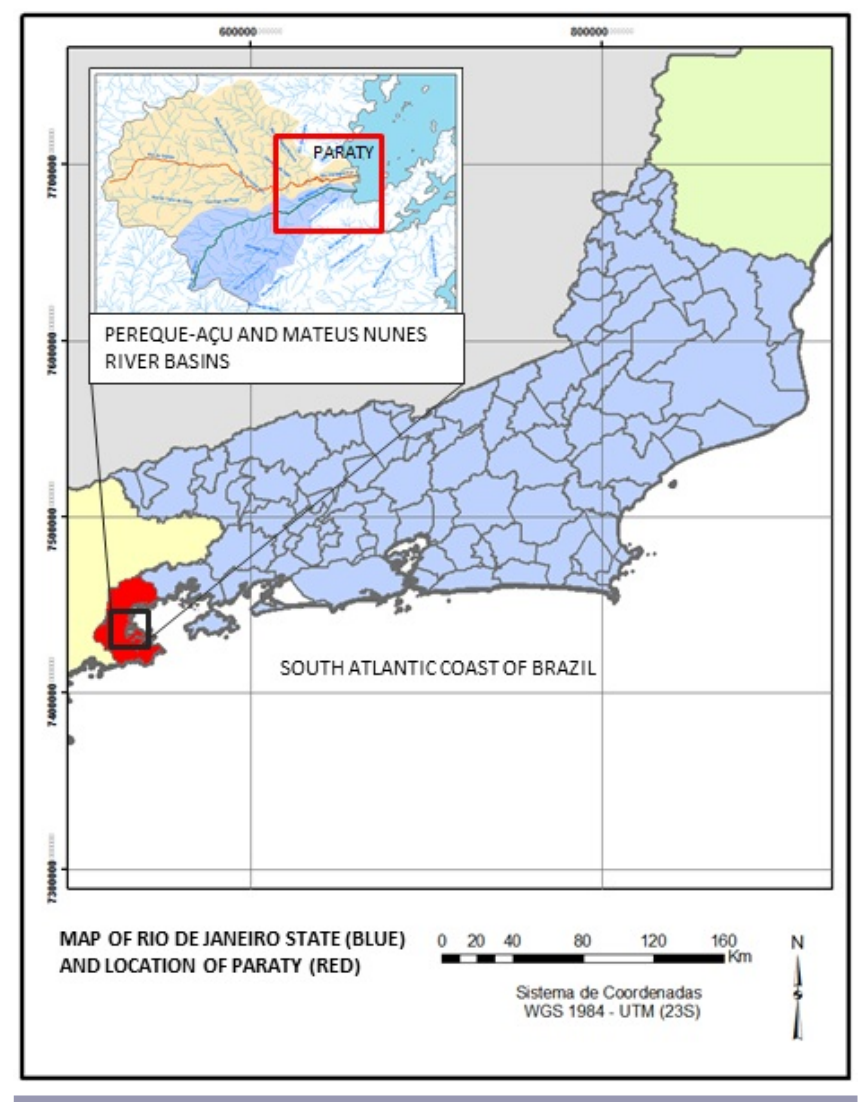

Our study area is examined at two scales of analysis: the broader scale considers the entire watersheds of both rivers, Perequê-Açu and Mateus Nunes, comprising an area of approximately 16,500 hectares (see location on Fig. 1 and hydrological characteristics in the Methodology section); on a more detailed level, the study focuses on the lower region of the basins, namely the urban and peri-urban floodplain of the city of Paraty, comprising an area of approximately 1000 hectares. A substantial part of this floodplain maintains ancient characteristics rooted in colonial land ownership regimes, and this is why the peri-urban landscape around Paraty is still marked by the presence of large open spaces. The most important areas are described and illustrated in the left image of Figure 2. Stretching approximately two miles west from the urban area, the lands usually known as "Bananal" (area A in left image of Fig. 2), owned by the former royal family, still present 
the characteristics of a large farm along which the river Mateus Nunes was realigned in the 19th century. Since the extraction of gold in Minas Gerais, these farms characterized the economic landscape of the Southwestern region of Brazil, signaling a distinct difference from other regions. Agriculture in Paraty has declined and today the remaining farms are mainly used for pasture. North of the old town, the area of Jabaquara (area B in Fig. 2A) is mainly composed of wetlands belonging to another large landowner. Although this area has been classified as an urban expansion area since the first 1972 Master Plan, it still remains largely untouched. The airport area (area C in Fig. 2A) also represents an important open space near the city. The remnants of the floodplain along Pereque-Açu river (area D in Fig. 2A) still present large open areas, although urbanization is proceeding. In a broader study of the municipality of Paraty, the urban research group from the Federal University of Rio de Janeiro (PROURB) coordinated by Tardim has reflected upon the system of open spaces in Paraty and put forward three possible functions for these peri-urban areas: (1) Enhancement of the ecosystem services provided by the watersheds, with potential to preserve vegetation, hydrography, and land structure; (2) A landscape perception area, involving a possible relation between natural and man-made landscapes; (3) Urban occupation as an opportunity to structure areas already in danger of uncontrolled urbanization (Tardim 2010). The uncontrolled urbanization currently poses the biggest threat to the cultural landscape of Paraty. Along the rivers Pereque-Açu and Corisco (a tributary of Mateus Nunes river), urban development is already occurring at a fast pace.

In the immediate upstream surroundings of the large properties described earlier, various neighborhoods have rapidly developed in the last 25 years, many of them driven by informal occupation and uncontrolled land use change processes. From 1985 onwards, pressures over land resources have been more intensely manifested through the emergence of new residential areas on previously rural land, the multiplication of formal and informal settlements in flood risk areas, and illegal occupation and deployment of urban subdivisions, in some cases sponsored by the municipality. Structural problems in such areas include the lack of housing for the most disadvantaged social groups, and poor sanitation services in the flood prone areas where they live. These problems result in serious consequences for the well-being of local communities, contributing to socially inequitable and environmentally unsustainable patterns of urban growth. In response to these problems, we aim to develop a better understanding of the dynamic relationship between upstream urbanization and downstream flooding, and use this understanding to develop land use scenarios which explore the trade-offs between the demand for new housing and the safeguarding of the peri-urban floodplains which provide waterflow regulation and other ecosystem services for urban inhabitants.

\section{METHODOLOGY}

In order to quantify the effects of hypothetical land use changes on flooding there is a wide range of available modeling tools, such as unidimensional and multidimensional models, using conservative or nonconservative equations (see Sousa 2010), each of which with its own advantages and limitations. The level of complexity and the resolution of the analysis do not have to be
Fig. 2. Current situation (description of main open spaces) and proposed scenario (river restoration and compact city).
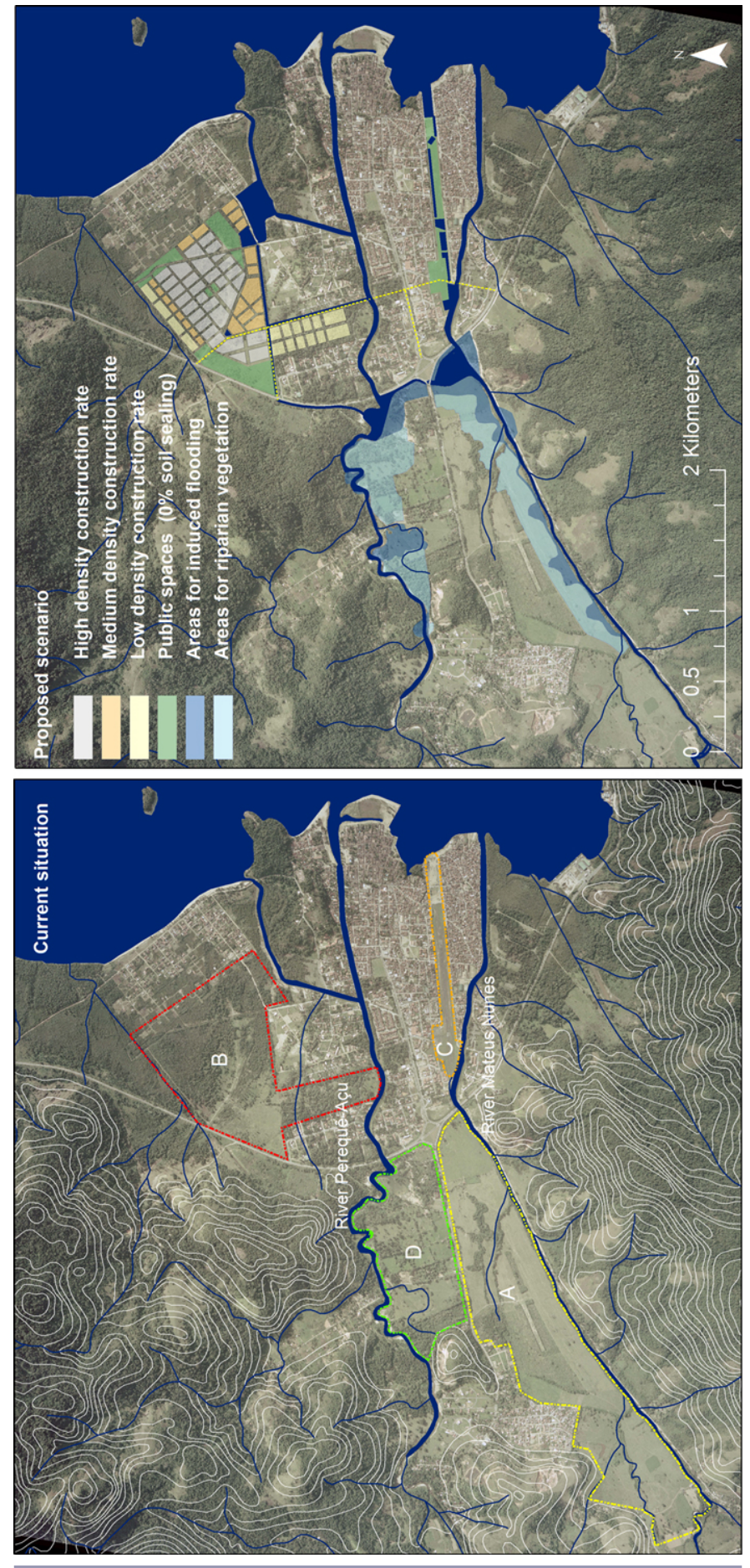

as high as possible, rather they need to be "fit for purpose", according to the level of detail provided by the available input data in the modeling process development. For our study, the mathematical model MODCEL, developed at the Laboratory of 
Computational Hydraulics of the Federal University of Rio de Janeiro (Mascarenhas and Miguez 2002) is an "off the shelf" model that provides a suitable choice for our experiment. MODCEL has the characteristics of a Quasi-2D (see Cunge et al. 1980) hydrodynamic model and is based on the concept of flow cells, whereby the territory is represented by a set of interconnected compartments along the entire watershed. The US Army Corps Engineers (1993) and Barnard et al. (2007) recommend the use of hydrodynamic models when rivers present low slope and in complex systems where drainage networks are divided and then reconnected again along the drainage network, as is the case in the lower regions of the Mateus Nunes and Perequê river basins.

MODCEL is able to reproduce a great variety of hydraulic patterns in an urban landscape and to consider a set of distributed measures in order to test the behavior of the urban drainage network. An important feature related to MODCEL is that flows may occur in different parts of the basin(s) independently, at the same time, and, eventually, as the flood increases these areas may act jointly. This hydrodynamic model, although it works through unidimensional hydraulic relations, is capable of representing water-flows in two dimensions. In fact, in the case of urban basins, the model is able to represent the flow exchange between surface cells and subterranean cells, usually representing drainage galleries, enabling the representation of water flow in three dimensions. If we want to consider peri-urban floodplains upstream of the urban area, Quasi-2D models are more adequate than unidimensional models because they allow a more systemic view of the functioning of the river system. In the context of our study, MODCEL allows for the testing of different possibilities of land uses, enabling a better understanding of their effect on water-flow regulation services, especially when severe flood problems occur with large inundation areas, when superficial flows and topography play major roles. The study has considered the combined entire watersheds of the rivers Perequê-Açu and Mateus Nunes, which run through the city of Paraty. The subdivision of watersheds in flow cells was carried out according to their topographical characteristics and urban typologies, comprising 378 cells representing lowland areas, 88 channel cells representing the rivers Pereque-Acu and Mateus Nunes and 67 cells representing the hillside areas.

Rainfall data were obtained from the rainfall station of Paraty. In order to calculate future changes in astronomical tides, tide regimes were inserted in the free software SisBaHia (Rosman 2011). The water flow coefficients, which are runoff (related to the absorption capacity of the soil) and manning (related to the roughness of the soil), are based on Wilken (1978) and American Society of Civil Engineers (1969), according to the characteristics of the soil coverage of the river basins under study. The runoff values and manning coefficients defined for this study are presented in Appendix 1.

After inserting all relevant data, the model is able to reproduce the current situation representing the reality of the Perequê-Açu and Mateus Nunes river basins, which constitutes the benchmark for comparing future scenarios. At this stage, calibration is an important step, aiming to reduce the uncertainties in the simplified representation of a real system, and ensure acceptable levels of confidence in the model. The calibration of the mathematical model was carried out by adjusting the hydrological parameters, so that the water discharges simulated by the model are similar to those observed in real events. This was done following a "trial and error" procedure, in which the parameters were adjusted manually through successive simulations and comparison between the observed and calculated flows, enabling the validation of the model (Bonganha et al. 2007). Calibration and validation of the model were therefore carried out by calculating the deviation between the flows calculated by MODCEL and the flow rates recorded in situ, adjusting the hydrography of the Pereque-Acu and Mateus Nunes rivers based on the representation of the concentration time of water flows for each watercourse and direct information collected from site visits. The deviations ranged from $-10.2 \%$ to $2.4 \%$. In addition to the flow, the water concentration time was also used for model calibration. The deviation between the calculated and the observed water flows allowed the modelling parameters inserted on MODCEL to be adjusted.

After calibrating the model based on the correct representation of the current situation, a future scenario was simulated for a time recurrence (TR) of a high rainfall event with a predicted likelihood of one in five years (TR of five years) and a TR of 25 years. This hypothetical scenario was developed based on the concepts presented in the Introduction and took into consideration the physical components of the basin, such as topography, urban occupation, and physical infrastructure, among others. This scenario emphasizes river restoration measures by reconnecting the meanders of the Mateus Nunes river, enhancing ecosystem services through tree planting along the floodplain (soft mitigation measures), and avoiding further occupation in upstream areas of the floodplain. This scenario also proposes a connection between the two hydrographic basins through the opening of a new canal along BR101 (Brazilian National Road 101, also known as Rio-Santos highway), admitting partial urban occupation of downstream areas of the floodplain, as illustrated in the right image of Figure 2.

Since this scenario was developed as a hypothesis for the present study, the measures adopted for this study are described in the following paragraphs in more detail:

(1) Restoration of Mateus Nunes river: the realignment of the Mateus Nunes river was designed to ensure the functioning of the river in a more natural environment. The new river sinuosity of Mateus Nunes was represented by using the Pereque-Acu sinuosity as a reference and restoring riparian vegetation. In addition, runoff values and manning coefficients were adjusted in order to represent the changes in land cover.

(2) Compact urban development: urban growth is directed to the remnants of available land located in downstream areas of BR101, bringing higher occupation rates in the Northern area of Jabaquara. The region upstream of BR101 highway is preserved from further urban occupation, functioning as a buffer zone between the urban area and the upstream regions of the floodplain.

(3) Construction of connected lakes between the Pereque-Acu and Mateus Nunes rivers: this measure aims to increase the water storage capacity in the upstream region of the BR101, enable the sharing of the water flow of both watercourses, and reduce the 
Fig. 3. Flood maps for the current situation (left) and proposed scenario (right) for a time recurrence (TR) of 5 years
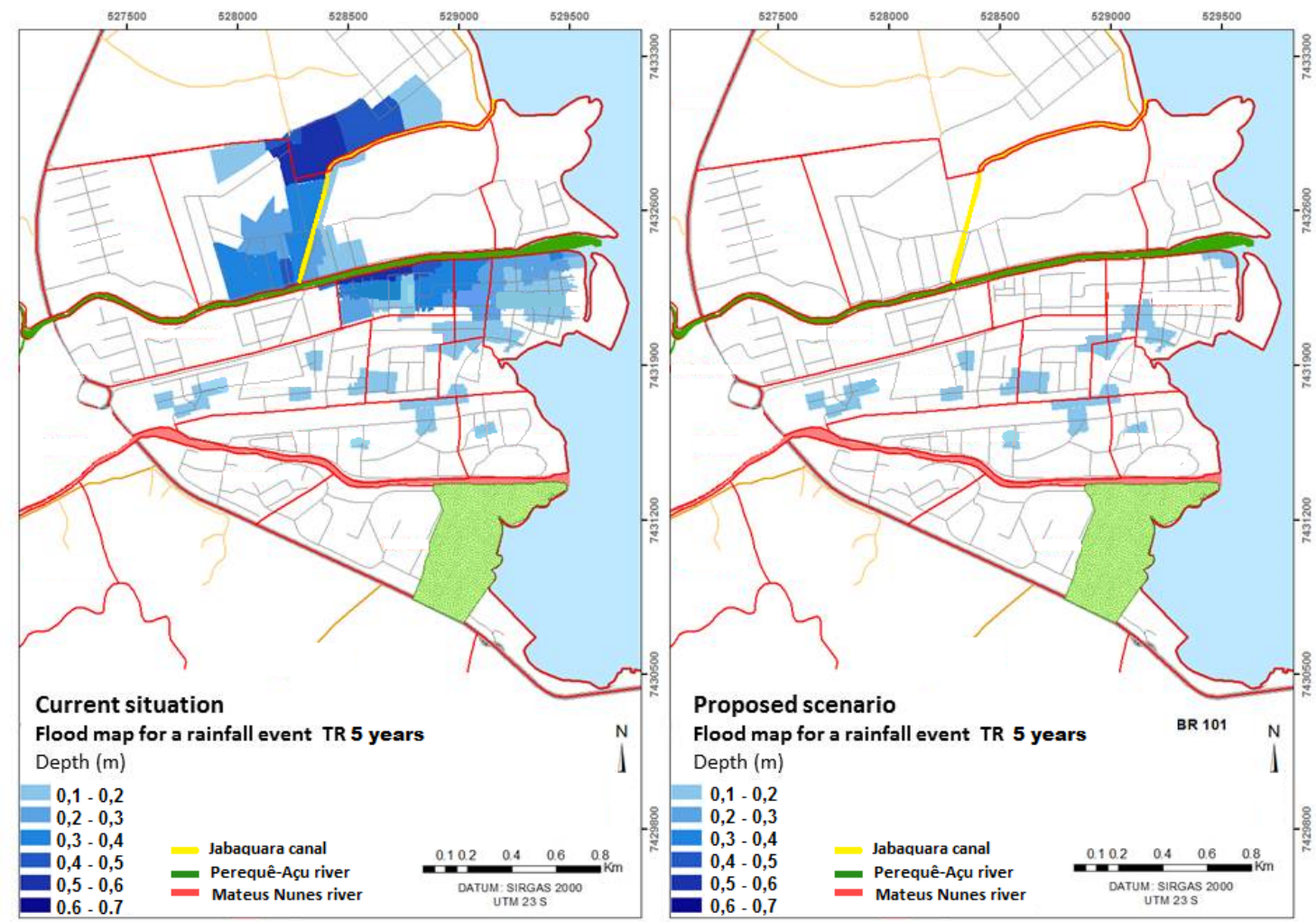

volume of water flowing into the city in the watershed. The storage areas have had their dimensions modified in order to represent the modified topography of these areas, allowing the transfer of water from one river basin to the other.

(4) Opening of new channels complementing the existing drainage network: The new channels were designed to increase the flexibility of both river systems and restore the natural functions of distributed water flow. The connecting channels were set after simulation tests in order to find the optimum width-depth ratio (width of $12 \mathrm{~m}$ and depth of $2.5 \mathrm{~m}$ ), and were designed to transfer sufficient volume of water from the Perequê-Açu without increasing the overflow of the Mateus Nunes river.

(5) Dredging of the Mateus Nunes and Perequê-Açu rivers along the stretch downstream of the BR101 highway: since both river banks already present a high degree of intervention along almost the entire length of their urban areas, it is believed that the current stage of sedimentation of the lower reaches of the rivers is not the result of natural processes. Thus, dredging both river systems in the stretch downstream of the BR101 highway in this scenario is considered a complementary intervention in order to remove the excess sediments observed in the current situation.

\section{RESULTS}

The simulation of the current conditions of the watershed of the Pereque-Acu and Mateus Nunes rivers resulted in flood maps that can be observed in Figure 3 and 4. On these maps it is possible to visualize the distributed impacts of land use change in the consolidated urban area, as well as the benefits produced by the measures proposed for improving water-flow regulation services.

For hydrological events of low magnitude, the flooded areas in the current situation are already significant, especially in the urban area surrounding the Perequê-Açu river and in the Jabaquara area. In this region, for a one in five year rainfall event, the resulting water depths range from $20 \mathrm{~cm}$ to $56 \mathrm{~cm}$. For events of 1 in 25 years, flooding reached $79 \mathrm{~cm}$. The Mateus Nunes river presents overflow at some points, especially on the right bank. In some neighborhoods, water levels of up to $26 \mathrm{~cm}$ are expected for a one in 25 year rainfall event.

The implementation of the measures proposed in the region upstream of the BR101, coupled with the opening of the new proposed canals, would eliminate the flooding caused by the overflow of the Perequê-Açu in rainfall events of one in five years, as shown in Figure 3. Flood areas were also eliminated in many areas for one in 25 year rainfall events, as shown in Figure 4. In Caborê and Jabaquara neighborhoods, considered to be at critical flood risk under current conditions, the flood abatement levels reached $60 \mathrm{~cm}$ and some areas of the city center had maximum water levels lowered by about $50 \mathrm{~cm}$. In Mateus Nunes river, maximum water levels were reduced by $10 \mathrm{~cm}$ for a rainfall event of one in five years and $22 \mathrm{~cm}$ for a rainfall event of one in 25 years. 
Fig. 4. Flood maps for the current situation (left) and proposed scenario (right) for a time recurrence (TR) of 25 years
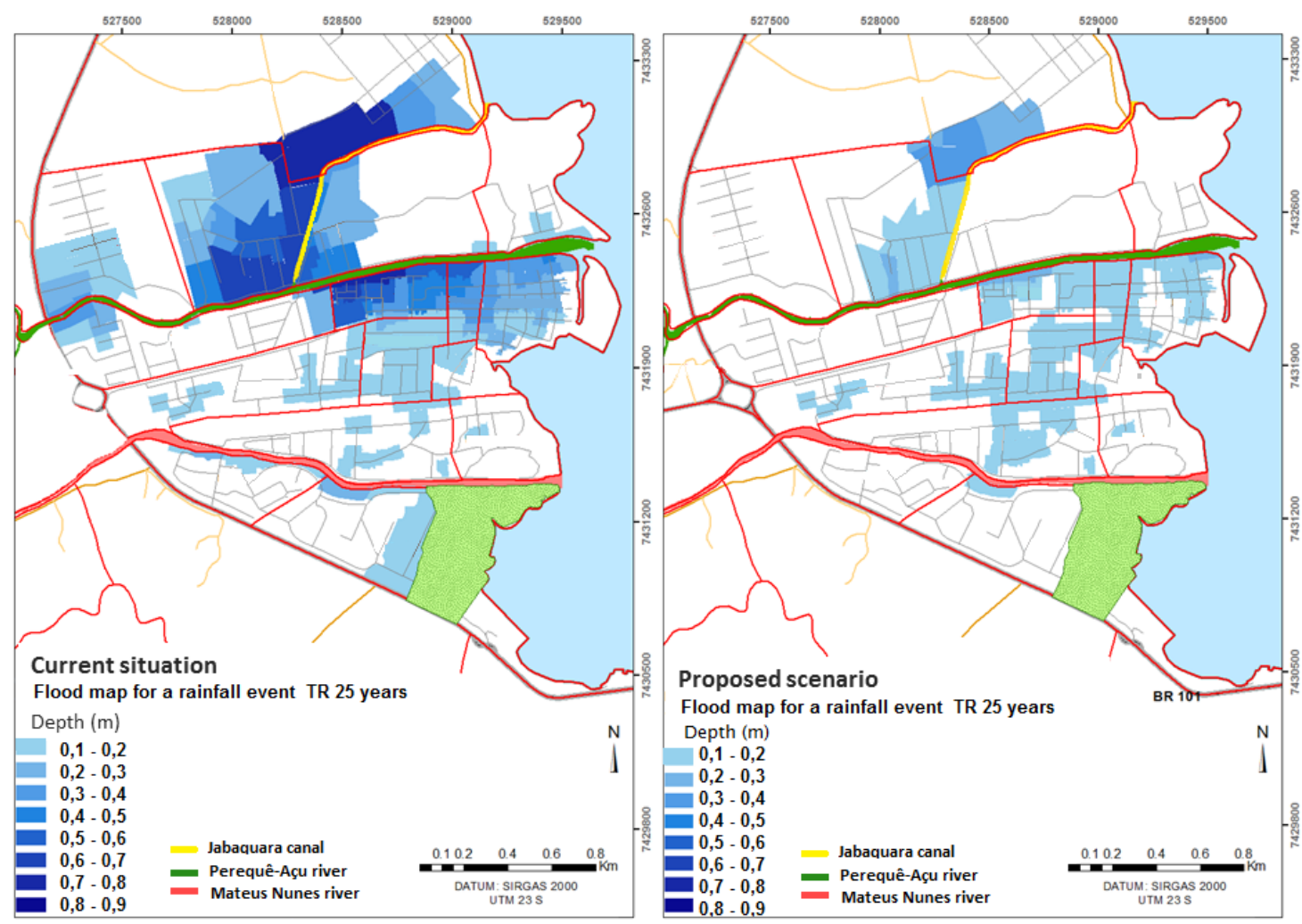

By comparing the flood maps for the current situation with the proposed scenario for extreme rainfall events of five years and 25 years it is noticeable that the impacts of land use change are more visible for smaller flood events. The proposed measures have been shown to be most efficient for a high rainfall event with a predicted likelihood of one in five years, also significantly lowering the water levels in situations of high rainfall events for the time recurrence of 25 years.

Figure 5 shows the profiles of maximum water levels in the two situations modeled for the Perequê-Açu and Mateus Nunes rivers, respectively, displaying the water flow over time for the section that crosses the BR101.

Overall, the proposed scenario presents lower water levels than the current situation in most flood prone areas of Paraty. As can be observed in Figure 5, the measures adopted in the proposed scenario bring significant improvements to the present situation by reducing peak flows in the Perequê-Açu river, slowing down the pressure in the case of coincidence with higher tides (i.e., when the town is threatened by high waters coming from both directions). On the other hand, this scenario showed higher peak levels than the current scenario in the Mateus Nunes river, while in the Perequê-Aêu river, the opposite occurred. This is due to the proposed link between these rivers; since the water volume contribution of the Perequê-Açu river basin is approximately twice that of Mateus Nunes, this link was tested in order to restore previous natural functions of water-flow exchange, allowing the overflow from Perequê-Açu into Mateus Nunes.

\section{DISCUSSION}

The results have shown the potential for improving water-flow regulation services, which may reduce urban flooding to a large extent. The visualization of such gains may encourage a more comprehensive evaluation of the benefits of preserving periurban floodplains, constituting strong arguments for the adaptation and designation of these territories as protected landscapes for flood mitigation and synergistic ecosystem services such as amenity, nonintrusive recreation, and the continuation of traditional and nonintensive agricultural activities. The quantitative analysis of flood mitigation benefits provides important information for the assessment of wetland values at the local level and may be a useful reference when designing strategies for the conservation of peri-urban landscapes. It should be noted that one of the most polemic issues in the literature about ecosystem services comes from the difficulty of precisely identifying the extent of the service (Pearce 1998, Boyer and Polasky 2004) and the value that can be put on it (Vandewalle et al. 2010). Carpenter et al. (2009) noted that some evaluation practices intended to improve ecosystem services are based on untested assumptions and sparse information, making it difficult 
Fig. 5. Hydrographs of the Perequê-Acu (above) and Mateus Nunes (below) rivers intersecting BR 101

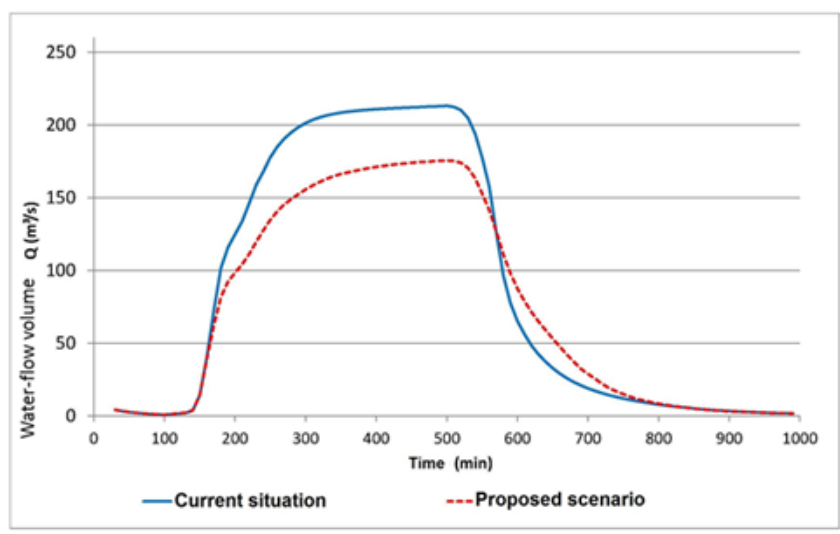

Hydrograph of the River Perequê-Açu crossing BR-101

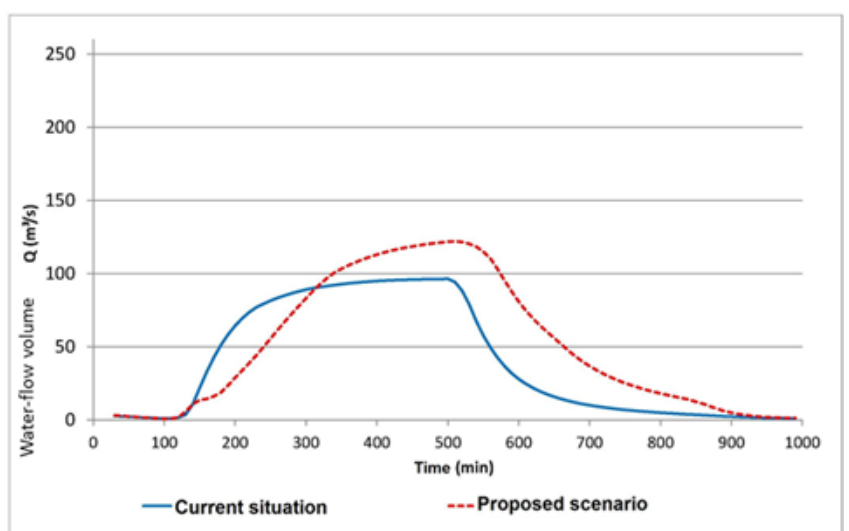

Hydrograph of the River Mateus Nunes crossing BR-101

to embed those concerns in the decision making process. Considering these limitations, our modeled scenarios provide quantifiable ecosystem services, which can be tailored to examine the trade-offs inherent in decisions that are actually being considered by relevant authorities. It is also important to consider that water-flow regulation services constitute nontransferable ecosystem services (Liu et al. 2010) and produce benefits for many, but do so through a geographically uneven distribution. This means that strategic resources for flood mitigation are location specific and need to be properly identified. The results of the present study contribute to a better understanding of the relationship between specific land resources and water-flow regulation services in a spatially explicit way. Visualizing gains and benefits from the preservation and enhancement of specific natural resources may effectively inform land use decisions, contributing to the conservation of cultural landscapes of high environmental value.

The results of the modeling exercise show that the use of river restoration measures in the upstream regions of built-up urban areas can restore an element of flexibility to the Perequê-Açu and Mateus Nunes river basins, which in the present situation has been lost by the modification of river geometry and the progressive introduction of physical infrastructure. According to our model calculations, the restoration of connections between fragmented ecosystems can be effective in slowing down the runoff from heavy rains and reduce peak flows when flooding occurs, by sharing the water volume in both watersheds. This confirms that watershed planning designed to strategically restore wetlands has the potential to provide dramatic benefits by restoring ecosystemlevel processes (functions) that maintain water resource integrity (White and Fennessy 2005). According to our model calculations, the proposed connection between both river basins can protect settlements and infrastructure as these allow an important share of the rainfall water to be retained when rainfall events coincide with higher sea tides. Complementary to these, the combination of bioengineering measures, such as reforestation in upstream areas of the basin and dredging of the river in downstream urban areas of the rivers, was shown to be effective in lowering water levels and storm water discharges in the mostly poorer urban areas that are currently prone to flooding. These findings confirm that an integrated approach to flood management (Miguez et al. 2012), using an appropriate combination of structural and nonstructural measures (see Rezende 2010) constitutes the most efficient way of reducing flooding in peri-urban environments.

We also saw that the adoption of higher density rates in lower regions of the basin can be effective in reducing the flooding impacts of urbanization. These findings are consistent with theories that emphasize the importance of promoting compact cities. In our experiment, while the densification of downstream areas would have a minimal impact on flood risk, the further occupation of the upstream areas along the floodplain will not only lead to the worsening of flood risks in the recently urbanized areas, but will also bring additional pressure to downstream areas, endangering the existing built heritage and implying future high costs of hard engineering infrastructure and maintenance services. These findings show the importance of land use decisions at the local level, and how they influence human exposure to flood risks in the future. In this regard, the Global Environment Outlook attaches particular significance to the risks of crossing thresholds, that is, the potential of reaching turning points in the relationship between people and the environment (United Nations Environment Programme 2007).

The results of our modeling exercise show that the adoption of a more concentrated pattern of urban development together with the preservation of key resources for flood prevention is a management option that may translate into mutual gains and multiple benefits. Research on the design of incentive policies to enhance the delivery of ecosystem services offers interesting possibilities that may well be used for the conservation of cultural landscapes. For example, it may be possible to draw on ecosystem services funds, in order to implement natural flood protection buffers such as forests, thus also contributing to reforestation targets (Jha et al. 2012). In the case of Paraty, the project recently launched by the Global Environment Facility, the "Integrated Management of the Ilha Grande Bay Ecosystem" (Global Environment Facility 2011) provides a special opportunity to introduce these issues as part of a broader set of environmental goals for the region. The main objective of this project is to achieve the long-term conservation and sustainable use of the Ilha Grande Bay Ecosystem, where the Pereque-Acu and Matheus Nunes river basins are located and where the biggest pressures from 
urbanization exist. It is noteworthy that one of the goals established by the project is the "mitigation of selected threats affecting the health of the Ilha Grande Bay Ecosystem and its ability to provide critical environmental goods and services". Such an ambitious project may constitute an opportunity for a more complete assessment of the many cultural values and other ecosystem services provided by the areas identified within the present study.

To encourage local governments to adopt policies for the adequate management of peri-urban floodplains requires a shift in the current trends of land use change and urban expansion. To support such a shift, it is essential that wetlands located in upstream reaches of urban areas are recognized as a collective good on which the safety and well-being of local communities ultimately depend. Hence, it is crucial to ensure that information about the full range of services provided by peri-urban flood plains is available to decision makers, and is presented in such a way that different decision options can be assessed. The acknowledgement of these "collective goods" implies a change of perspective with regard to the management of these territories, which can no longer be defined only by the sum of private interests and socioeconomic pressures, but rather, by the recognition of a collective interest (Leis 1995). It is noteworthy that the Millennium Ecosystem Assessment (Millennium Ecosystem Assessment 2005) recognized that when both the market and nonmarket economic benefits of wetlands are included, the total economic value of unconverted lands is often greater than that of converted land. It is thus reasonable to argue that if all economic, social, and environmental benefits are considered together, the adaptation of floodplain remnants to appropriate uses could be of higher worth than their conversion into new residential areas.

The use of MODCEL for our study territory has proven to be useful not only to estimate the effects of the optimization of waterflow regulation services in reducing urban flooding, but it can also be used in order to introduce principles of equity and social justice into land use decisions. The cell model establishes a causal link between changes in land use and the flooding externalities experienced by downstream parcels of land, and hence the people who live there. As is the case in many cities in developing countries, the urban areas in Paraty that are most prone to flooding are largely inhabited by poorer residents. The understanding of causal relations between different land uses allows us to identify who bears the cost of the conversion of urban land in terms of increased flood risks as a result of these actions. It also makes it possible to identify beneficiaries and providers of water-flow regulation services, creating a direct connection between those who benefit from ecosystem services and those who can deliver them.

\section{CONCLUSIONS}

The management of peri-urban floodplains requires not only the use of a larger set of instruments to visualize the ecosystem services associated with a certain watershed, but also a broader understanding by managers and citizens on how this information may be useful for managing cultural landscapes. We have shown that the adoption of proactive measures for enhancing water-flow regulation services may bring significant benefits for the conservation of existing built heritage and for the welfare of urban residents. Our findings suggest that the adoption of an ecosystem approach may well provide a rationale for informing land use decisions, by bringing quantifiable data that can support conservation strategies for peri-urban areas. The merits of preservation or conversion depend on many factors that are subject to change, and land allocation decisions in peri-urban areas need to be properly assessed in light of current socioeconomic factors with strong influences over land use change processes, especially if irreversible loss is involved. In such cases, providing more sustainable solutions to housing needs in growing cities, while aiming to reduce the occurrence of urban flooding, may imply the conversion of selected areas for urban development with higher density rates, in order to compensate the conservation of strategic natural resources for water-flow regulation. In this case, the pressure for urbanizing the land upstream of the built-up urban area is high due to the attractiveness of the town and its environmental setting. It is therefore somehow paradoxical that concerns about the conservation of the existing built heritage leads to sprawl in the upstream rural area, which in turn threatens the conservation status of the town and the safety of its inhabitants.

The conservation of cultural landscapes may come by way of a more integrated understanding of the value of our life-support systems, recognizing the interdependency between built heritage and its immediate surroundings. Urban expansion processes and associated land use change in peri-urban areas create substantial reasons for concern regarding the ability to sustain the ecosystem services required for human well-being. These concerns increase with the acknowledged uncertainties regarding future changes caused by climatic factors. The example of Paraty demonstrates how built capital and cultural heritage are created under economic conditions related to natural resource extraction, but once the urban setting develops, it provides a new rationale for the use of surrounding landscapes. Hence, the process that created cities, founded on economic growth, if continued in an uncontrolled manner, becomes a threat to the very city itself. With regard to water-flow regulation, as well as to other ecosystem services, benefits from preservation and conversion of land resources may be combined through the establishment of strategies and management arrangements in order to improve the benefits derived both from natural conditions and human actions. This means that sustaining ecosystem services in cultural landscapes is not just a question of passive preservation, but can also be an active pursuit, and even though development processes may have destructive consequences, it is also within our power to enrich the environment in which we live.

Responses to this article can be read online at: http://www.ecologyandsociety.org/issues/responses. $\mathrm{php} / 6482$

\section{Acknowledgments:}

The authors gratefully acknowledge funding by the Coordination for the Improvement of Higher Education Personnel (CAPES), the Foundation for Support of Research in the State of Rio de Janeiro (FAPERJ, ref: 100-223/2014) and the Natural Environment Research Council (ref: NE/I003819/1). 


\section{LITERATURE CITED}

Acharya, G. 2000. Approaches to valuing the hidden hydrological services of wetland ecosystems. Ecological Economics 35 (1):63-74. [online] URL: http://www.sciencedirect.com/science/ article/pii/S0921800900001683

American Society of Civil Engineers. 1969. Design and construction of sanitary and storm sewers. American Society of Civil Engineers, New York, USA.

Andoh, R., and K. Iwugo. 2002. Sustainable urban drainage systems: a UK perspective. Pages 1-16 in E. W. Strecker, and W. C. Huber, editors. Global solutions for urban drainage. American Society of Civil Engineers, Reston, Virginia, USA. http://dx.doi. org/10.1061/40644(2002)19

Barnard, T, T. E. Barnard, A. W. Kuch, G. R. Thompson, S. Mudaliar, and B. C. Phillips. 2007. Evolution of an integrated 1D/2D modeling package for urban drainage. Computational Hydraulics International 18:343-365.

Batker, D., M. Kocian, B. Lovell, J. Harrison-Cox. 2010. Flood protection in the Chealis River basin. Earth Economics, Tacoma, USA.

BMT WBM. 2009. Evaluating options for water sensitive urban design - a national guide. Joint Steering Committee for Water Sensitive Cities, Sydney, Australia.

Bonganha, C., N. Guiguer, S. Pereira, L. Oliveira, and M. Ribeiro. 2007. Conceitos e fundamentos da modelagem matemática para gerenciamento de recursos hídricos subterrâneos. Analytica 30:116-120.

Boyer, T., and S. Polasky. 2004. Valuing urban wetlands, a review of non-market valuation studies. Wetlands 24-4:744-755. http:// dx.doi.org/10.1672/0277-5212(2004)024[0744:VUWARO]2.0.CO;2

Carpenter, S., H. Mooney, J. Agard, D. Capistrano, R. DeFries, S. Díaz, T. Dietz, A. Duraiappah, A. Oteng-Yeboah, H. Pereira, C. Perrings, W. Reid, J. Sarukhan, R. Scholes, and A. Whyte. 2009. Science for managing ecosystem services: beyond the Millennium Ecosystem Assessment. Pages 1305-1312 in Proceedings of the National Academy of Sciences of the USA 106(5). http://dx.doi. org/10.1073/pnas.0808772106

Corkindale, J. 2007. The potential role of market-based instruments in the economic optimisation of investment in flood risk management. UK Environment Agency, London, UK.

Cunge, J., F. Holly Jr, and A. Verwey. 1980. Practical aspects of computational river hydraulics. Pitman Advanced Publishing Program, London, UK.

Cury, I. 2002. A evolução urbana e fundiária de Parati do séc. XVII até o séc. XX, em face da adequação das normas de proteção de seu patrimônio cultural. Thesis. Faculdade da Arquitetura e Urbanismo, Universidade de São Paulo, São Paulo, Brazil.

De Groot, R., R. Alkemade, L. Braat, L. Hein, and L. Willemen. 2010. Challenges in integrating the concept of ecosystem services and values in landscape planning, management and decision making. Ecological Complexity 7:260-272. http://dx.doi. org/10.1016/j.ecocom.2009.10.006
Directorate-General Environment. 2011. Towards better environmental options for flood risk management. Directorate General Environment of the European Commission, Brussels, Belgium. [online] URL: http://ec.europa.eu/environment/water/ water-framework/index en.html

Emerton, L. 2005. Values and rewards: counting and capturing ecosystem water services for sustainable development. World Conservation Union, Ecosystems and Livelihoods Group Asia. International Union for the Conservation of Nature (IUCN), Gland, Switzerland. http://dx.doi.org/10.2305/IUCN.CH.2005.12. en

Global Environment Facility. 2011. Integrated management of the Ilha Grande Bay ecosystem (Project Document). Global Environment Facility, Washington, D.C., USA.

Haller, T. (editor). 2010. Disputing the floodplains. Institutional change and the politics of resource management in African wetlands. African Social Studies Series. Brill, Boston, USA. http://dx.doi. org/10.1163/ej.9789004185326.i-454

Jha, A. K., R. Bloch, and J. Lamond. 2012. Cities and flooding: a guide to integrated urban flood risk management for the 21st Century. World Bank and Global Facility for Disaster Reduction and Recovery, Washington, D. C., USA. http://dx.doi. org/10.1596/978-0-8213-8866-2

Kloss, C., and C. Calarusse. 2006. Rooftops to rivers: green strategies for controlling stormwater and combined sewer overflows. Natural Resources Defense Council, Low Impact Development Center, and University of Maryland School of Public Policy, Maryland, USA. [online] URL: http://www.nrdc.org/water/ pollution/rooftops/rooftops.pdf

Kousky, S., S. Olmstead, M. Walls, A. Stern, and M. Macauley. 2011. The role of land use in adaptation to increased precipitation and flooding: a case study in Wisconsin's Lower Fox River basin. Resources for the future, Washington, D. C., USA.

Leis, H. 1995. Introdução à questão metodológica. In A. Diegues, editor. Conflitos sociais e meio ambiente: desafios políticos e conceituais. Instituto Brasileiro de Análises Sociais e Econômicas (IBASE), Rio de Janeiro, Brazil.

Liu, S., R. Costanza, S. Farber, and A. Troy. 2010. Valuing ecosystem services: theory, practice and the need for a transdisciplinary synthesis. Ecological Economics Reviews. 1185:54-78.

Mascarenhas, F., and M. Miguez. 2002. Urban flood control through a mathematical cell model. Water International 27 (2):208-218. http://dx.doi.org/10.1080/02508060208686994

Miguez, M., A. Verol, and P. Carneiro. 2012. Sustainable drainage systems: an integrated approach, combining hydraulic engineering design, urban land control and river revitalisation aspects. Chapter 2 in M. S. Javaid, editor. Drainage Systems. InTech, Rio de Janeiro, Brazil.

Millennium Ecosystem Assessment. 2005. Ecosystems and human well-being: synthesis. Island Press, Washington, D. C., USA.

Mitchell, V., A. Deletic, T. Fletcher, B. Hatt, and D. McCarthy. 2006. Achieving multiple benefits from stormwater harvesting. T. 
Fletcher and A. Deletic, editors. In Proceedings of $7^{\text {th }}$ International Conference on Urban Drainage Modelling and the $4^{\text {th }}$ International Conference on Water Sensitive Urban Design (Melbourne, Australia, 2006). Monash University, Clayton, Victoria, Australia.

Pearce, D. 1998. Environmental appraisal and environmental policy in the European Union. Environmental and Resource Economics 11(3-4):489-501. http://dx.doi.org/10.1023/A:1008207715184

Rezende, O. 2010. Avaliação de medidas de controle de inundações em um plano de manejo sustentável de águas pluviais aplicado à baixada fluminense. Instituto Alberto Luiz Coimbra de PósGraduação e Pesquisa de Engenharia (COPPE), Universidade Federal do Rio de Janeiro, Rio de Janeiro, Brazil.

Rogers, R. 1997. Cities for a small planet. Faber and Faber, London, UK.

Rosman, P., 2011. Referência técnica do SisBaHiA. Instituto Alberto Luiz Coimbra de Pós-Graduação e Pesquisa de Engenharia (COPPE), Universidade Federal do Rio de Janeiro, Rio de Janeiro, Brazil.

Schuyt, K. 2005. Economic consequences of wetland degradation for local populations in Africa, Ecological Economics 53:177-190. http://dx.doi.org/10.1016/j.ecolecon.2004.08.003

Sousa, M. 2010. Comparação entre ferramentas de modelagem unidimensional e quasi-bidimensional, permanente e nãopermanente, em planejamento e projetos de engenharia hidráulica. Thesis. Instituto Alberto Luiz Coimbra de Pós-Graduação e Pesquisa de Engenharia (COPPE), Universidade Federal do Rio de Janeiro, Rio de Janeiro, Brazil.

Tardim, R. 2010. Projeto: Análise, ordenação e projeto da paisagem - Paraty. Observatório da Paisagem/ Nucleo de Interdisciplinaridade de pesquisas em paisagens/ Programa de pós-graduação em urbanismo/ Faculdade de Arquitetura e Urbanismo/ Universidade Federal do Rio de Janeiro, Rio de Janeiro, Brazil.

United Nations Environment Programme. 2007. Global environment outlook. Progress Press, Valletta, Malta. [online] URL: http://www.unep.org/geo/geo4/report/GEO-4_Report_Full_en. pdf

US Army Corps Engineers. 1993. River hydraulics: engineer manual. Department of the Army/U.S. Army Corps of Engineers, Washington, D. C., USA.

US Department of Defense. 2010. Unified facilities criteria (UFC) design: low impact development manual. United States Department of Defense, Washington, USA. [online] URL: http:// www.wbdg.org/ccb/DOD/UFC/ufc 3210 10.pdf

Vandewalle, M., F. de Bello, M. Berg, T. Bolger, S. Dolédec, F. Dubs, C. Feld, R. Harrington, P. Harrison, S. Lavorel, P. Martins da Silva, M. Moretti, J. Niemelä, P. Santos, T. Sattler, T. Sousa, M. Sykes, A. Vanbergen, and B. Woodcock. 2010. Functional traits as indicators of biodiversity response to land use changes across ecosystems and organisms. Biodiversity and Conservation 19:2921-2947. http://dx.doi.org/10.1007/s10531-010-9798-9

Vuuren, W., and P. Roy 1993. Private and social returns from wetland preservation versus those from wetland conversion to agriculture. Ecological Economics 8:289-305. [online] URL:
http://www.sciencedirect.com/science/article/pii/092180099390063C http:// dx.doi.org/10.1016/0921-8009(93)90063-C

White, D., and S. Fennessy. 2005. Modeling the suitability of wetland restoration potential at the watershed scale. Ecological Engineering 24:359-377. http://dx.doi.org/10.1016/j.ecoleng.2005.01.012

Wilken, P. 1978. Engenharia de drenagem superficial. Companhia de Tecnologia de Saneamento Ambiental, São Paulo, Brazil. 
Appendix 1. Values.

Table A1.1. Runoff values used for the study area.

\begin{tabular}{ll}
\hline Land use and coverage & Runoff \\
\hline forests & 0.2 \\
grasses & 0.4 \\
woods & 0.35 \\
agricultural use & 0.3 \\
swamp & 0.8 \\
urban - high density & 0.75 \\
urban - medium density & 0.6 \\
urban- low density & 0.5 \\
\hline
\end{tabular}

Table A1.2. Manning values used for the study area.

\begin{tabular}{ll}
\hline Soil type & Manning \\
\hline Road in rural area & 0.08 \\
Road in urban area & 0.06 \\
Grasses & 0.18 \\
Forest in floodplain area & 0.15 \\
Forest in slope area & 0.25 \\
\hline
\end{tabular}

